\title{
Korelasi antara Letak Ujung Kateter Lumen Ganda Femoralis Jangka Pendek Non-tunneling dengan Laju Aliran darah pada Saat Hemodialisis di RSUP Prof Dr. R. D. Kandou
}

\author{
${ }^{1}$ Fery Purba, ${ }^{2}$ Richard Sumangkut, ${ }^{2}$ Djoni E. Tjandra
}

\author{
${ }^{1}$ PPDS Ilmu Bedah Fakultas Kedokteran Universitas Sam Ratulangi Manado \\ ${ }^{2}$ Divisi Bedah Vaskuler Bagian Ilmu Bedah Fakultas Kedokteran Universitas Sam Ratulangi \\ Manado \\ Email: fery.purbatamba@yahoo.com
}

\begin{abstract}
Patients with end-stage renal failure are unable to survive without dialysis or renal transplantation. To achieve effective dialysis using a double lumen catheter, placement of the catheter tip plays an important role because it may affect blood flow/Quick of Blood (QB). The selection of femoral vein access is more favorable in critical patients. This study was aimed to obtain the correlation between the tip position of the non-tunneling short-term femoral double lumen catheter (DLC) and QB at the time of hemodialysis. This was an analytical correlative and prospective study with a cross-sectional design in patients with endstage renal failure undergoing hemodialysis using a non-tunneling short-term femoral DLC. This study was conducted at the Hemodialysis Installation of Prof. Dr. R. D. Kandou Hospital Manado. Data were analyzed by using the Pearson's $r$ test. The results showed that there were 31 patients enrolled in this study. The Pearson's $r$ test obtained an $r$ of 0.147 (statistically weak) and Sig (2-tailed) of 0.430 which showed no correlation but the scatter plot showed a tendency of a weak positive relationship. Conclusion: There was no significant correlation between $\mathrm{Qb}$ and the tip position of DLC, albeit, there was a tendency of a weak positive relationship. Increasing the number of samples will more accurately predict the presence or absence of the correlation between $\mathrm{Qb}$ and the tip position of the DLC.
\end{abstract}

Keywords: DLC, QB, hemodialysis

\begin{abstract}
Abstrak: Pasien dengan penyakit ginjal stadium akhir tidak dapat mempertahankan hidup tanpa dukungan terapi pengganti ginjal yaitu dialisis atau transplantasi ginjal. Untuk mencapai dialisis yang efektif dengan menggunakan kateter lumen ganda, penempatan kateter berperan penting karena dapat memengaruhi aliran darah/Quick of Blood (QB). Pemilihan akses vena femoralis lebih menguntungkan pada pasien kritis. Penelitian ini bertujuan untuk mengetahui korelasi letak ujung kateter lumen ganda femoralis jangka pendek (DLC) dengan QB pada saat hemodialisis. Jenis penelitian ialah analitik korelatif dan prospektif dengan desain potong lintang. Subyek penelitian ialah pasien dengan gagal ginjal tahap akhir yang menjalani hemodialisis menggunakan kateter lumen ganda femoralis jangka pendek non-tunneling. Penelitian dilakukan di Instalasi Hemodialisis RSUP Prof. Dr. R. D. Kandou, Manado. Data dianalisis menggunakan koefisien korelasi Pearson. Hasil penelitian mendapatkan 31 pasien sebagai subyek. Hasil analisis koefisien Pearson terhadap korelasi antara letak ujung DLC dan QB memperlihatkan hubungan statistik lemah $(r=0,147)$ dengan Sig (2-tailed) 0,430 yang menunjukkan tidak terdapat hubungan bermakna tetapi pada scatter plot terlihat adanya kecenderungan hubungan positif lemah. Simpulan: Tidak terdapat korelasi bermakna antara $\mathrm{Qb}$ dan letak ujung DLC tetapi terdapat kecenderungan hubungan positif lemah. Menambah jumlah sampel akan lebih akurat untuk memrediksi ada tidaknya hubungan antara $\mathrm{Qb}$ dan letak ujung DLC.
\end{abstract}

Kata kunci: DLC, laju aliran dara (QB), hemodialisis 
Penyakit ginjal stadium akhir merupakan gangguan fungsi renal yang progresif dan irreversible dimana kemampuan tubuh gagal untuk mempertahankan metabolisme serta keseimbangan cairan dan elektrolit yang selanjutnya menyebabkan uremia. Pasien dengan penyakit ginjal stadium akhir tidak dapat mempertahankan hidup tanpa dukungan terapi pengganti ginjal yaitu dialisis atau transplantasi ginjal. ${ }^{1}$ Tujuan dialisis ialah untuk mengurangi morbiditas, meningkatkan kualitas hidup, dan memperpanjang masa harapan hidup., Untuk mencapai tujuan ini dibutuhkan penanganan hemodialisis. yang efektif.

Hemodialisis yang efektif merupakan salah satu faktor penting yang berperan dalam menurunkan morbiditas dan mortalitas pasien sedangkan dialisis yang tidak efektif merupakan salah satu faktor penyebab kematian pasien tersebut. ${ }^{4,5}$ Terdapat banyak survei yang menunjukkan hubungan antara dosis dialisis dengan mortalitas dan morbiditas pasien. ${ }^{6,7}$ Hemodialisis yang efektif dapat menurunkan morbiditas dan biaya perawatan. ${ }^{8}$ Borzou et al. ${ }^{9}$ mendapatkan bahwa laju aliran darah yang lebih tinggi dapat meningkatkan efikasi hemodialisis dan akan menurunkan angka morbiditas dan mortalitas pasien yang tergantung hidupnya karena penyakit ginjal.

Pada tahun 1997, the Standard of Practice Committee of the Society of Cardiovascular and Interventional Radiology memublikasikan panduan Quality Improvement Guidelines for Central Access. Dokumen ini tidak secara khusus membahas posisi ujung kateter, namun panduannya mendefinisikan letak kateter secara sukses sebagai pengenalan kateter ke dalam sistem vena dengan lokasi ujung kateter yang diinginkan dan fungsi penggunaan kateter. Pernyataan ini menunjukkan bahwa letak ujung kateter ditentukan oleh operator. Oleh karena itu, kemampuan untuk mendapatkan akses vaskular yang cepat dan akurat menjadi keterampilan yang sangat penting bagi dokter perawatan kritis dan darurat. ${ }^{10}$

Salah satu metode yang paling umum untuk mendapatkan akses vena sentral dalam situasi darurat ialah melalui kanulasi vena femoralis. Teknik penempatan kateter vena femoralis secara akurat tergantung pada pemilihan pasien yang tepat dan pengetahuan tentang anatomi. Keadaan klinis pasien menentukan pemilihan tempat insersi kateter vena sentral. Penentuan lokasi akses yang mudah memiliki kerugian dan keuntungan yang tergantung dari keadaan klinis penderita. Pemilihan daerah femoralis lebih menguntungkan pada pasien yang sakit kritis karena area femoralis relatif bebas dari alat pemantau dan akses jalan nafas lainnya. ${ }^{10}$

Waktu penggunaan kateter lumen ganda femoral jangka pendek juga berperan penting untuk mencegah komplikasi yang akan berkaitan dengan mortalitas. Banyak faktor yang diduga memengaruhi aliran dialisat dari segi kateter itu sendiri. Faktorfaktor yang ada pada kateter tersebut di antaranya diameter kateter, letak ujung kateter, bentuk ujung kateter, dan lapisan lumen ganda itu sendiri. ${ }^{10}$ Konsensus Dialisis Pernefri (2003) menyampaikan bahwa akses vaskular yang adekuat dapat mengalirkan darah dengan kecepatan minimal 200-300 mL/ menit. ${ }^{11}$

Penelitian ini bertujuan untuk mengetahui korelasi letak ujung kateter lumen ganda (double lumen catheter/DLC) femoralis jangka pendek non-tunneling dan laju aliran darah Quick of blood (Qb) saat hemodialisis

\section{METODE PENELITIAN}

Jenis penelitian ini ialah analitik korelatif dan prospektif dengan desain potong lintang. Penelitian dilakukan di Instalasi Hemodialisis RSUP Prof. Dr. R. D. Kandou Manado sejak bulan Maret sampai dengan Mei 2018. Subyek penelitian ialah pasien gagal ginjal yang menjalani hemodialisis dengan menggunakan kateter lumen ganda femoralis jangka pendek non-tunneling.

Analisis data dilakukan dengan menggunakan koefisien korelasi Pearson

\section{HASIL PENELITIAN}

Selama masa penelitian sejak Maret 
sampai dengan Mei 2018 didapatkan sebanyak 42 pasien tetapi hanya 31 pasien yang memenuhi kriteria inklusi dengan usia tertua 89 tahun dan usia termuda 19 tahun. Distribusi berdasarkan jenis kelamin menunjukkan 25 pasien berjenis kelamin perempuan dan 17 pasien berjenis kelamin laki-laki.

Hubungan antara Qb dan letak DLC dianalisis dengan menggunakan uji korelasi Pearson yang mendapatkan adanya hubungan statistik lemah $(r=0,147)$ dengan Sig. (2tailed) 0,430 yang menunjukkan tidak terdapat hubungan bermakna antara keduanya (Tabel 1).

Analisis data berdasarkan usia dan $\mathrm{Qb}$ menunjukkan adanya hubungan lemah ( $r=0,126)$ dengan Sig. (2-tailed) 0,464 yang menunjukkan tidak terdapat hubungan bermakna antara keduanya (Tabel 2).

Korelasi data antara jenis kelamin dan Qb diuji dengan uji T mendapatkan rerata hasil Qb pada laki-laki sebesar 166,8 dengan standar deviasi 48,4 sedangkan pada perempuan didapatkan rerata hasil $\mathrm{Qb}$ sebesar 129,6 dengan standar deviasi 73,6 (Tabel 3).

Tabel 1. Hubungan antara Qb dan letak DLC

\begin{tabular}{llcc}
\hline & & QB & $\begin{array}{c}\text { Letak } \\
\text { DLC }\end{array}$ \\
\hline QB & Pearson correlation & 1 & 0,147 \\
& Sig. (2-tailed) & & 0,430 \\
& N & 36 & 31 \\
Letak & Pearson correlation & 0,147 & 1 \\
DLC & Sig. (2-tailed) & 0,430 & \\
& N & 31 & 37 \\
\hline
\end{tabular}

Tabel 2. Hubungan antara $\mathrm{Qb}$ dan usia

\begin{tabular}{llcc}
\hline & & QB & Usia \\
\hline QB & Pearson correlation & 1 & 0,126 \\
& Sig. (2-tailed) & & 0,464 \\
& N & 36 & 36 \\
Usia & Pearson correlation & 0,126 & 1 \\
& Sig. (2-tailed) & 0,464 & \\
& N & 36 & 42 \\
\hline
\end{tabular}

Tabel 3. Analisis hubungan antara $\mathrm{Qb}$ dan jenis kelamin

\begin{tabular}{cccccc}
\hline & $\begin{array}{c}\text { Jenis } \\
\text { kelamin }\end{array}$ & N & Mean & Std. Dev & $\begin{array}{c}\text { Std. Error } \\
\text { Mean }\end{array}$ \\
\hline Qb & Laki-laki & 19 & 166,8421 & 48,42550 & 11,10957 \\
& Perempuan & 23 & 129,5652 & 73,63783 & 15,35455 \\
\hline
\end{tabular}

\section{BAHASAN}

Selama masa penelitian Maret sampai Mei 2018, didapatkan sebanyak 42 pasien sebagai sampel; dari jumlah tersebut hanya 31 pasien yang memenuhi kriteria inklusi dengan usia tertua 89 tahun dan usia termuda 19 tahun. Berdasarkan jenis kelamin didapatkan 25 pasien berjenis kelamin perempuan dan 17 pasien berjenis kelamin laki-laki.

Hasil analisis koefisien korelasi Pearson memperlihatkan hubungan positif lemah $(\mathrm{r}=0,147)$ dengan Sig. (2-tailed) 0,430 yang menunjukkan tidak terdapat hubungan bermakna antara Qb dengan letak ujung DLC namun pada scatter plot dapat dilihat bahwa terdapat kecendrungan hubungan positif lemah. Letak ujung DLC di vena kava inferior dan diameter yang lebih besar pada pembuluh darah tersebut menyebabkan kejadian resirkulasi lebih minimal yang berakibat nilai $\mathrm{Qb}$ yang lebih tinggi dibandingkan dengan insersi pada vena iliaka. Korelasi ini dapat dilihat dari anatomi sistem vena manusia. Vena iliaka komunis terbentuk oleh vena iliaka eksternal dan vena iliaka internal. Diameter vena iliaka komunis ialah $17,8 \pm 2,86 \mathrm{~mm}$ (kisaran 12,0-22,5 $\mathrm{mm}$ ) pada tingkat distal dari persilangan pembuluh darah tersebut. Diameter vena iliaka eksternal ialah $16 \mathrm{~mm}$ sedangkan diameter vena kava inferior ialah 10-26 mm dengan rerata $19 \pm 5 \mathrm{~mm} .^{12}$

Hasil analisis koefisien korelasi Pearson menunjukkan tidak terdapat hubungan bermakna antara Qb dengan letak ujung 
DLC. Diduga penambahan jumlah sampel dapat memperlihatkan adanya hubungan lebih kuat yang dapat digunakan sebagai dasar penelitian selanjutnya.

Analisis data berdasarkan usia dan $\mathrm{Qb}$ memperlihatkan adanya hubungan lemah $(\mathrm{r}=0,126)$ dengan hasil Sig. (2-tailed) 0,464 yang menunjukkan tidak terdapat hubungan secara statisik. Dari analisis tersebut dapat disingkirkan adanya bias usia pada penelitian ini oleh karena tidak terdapat hubungan bermakna antara usia dan Qb. Hal ini sesuai dengan penelitian Patil et al. ${ }^{13}$ yang menunjukkan bahwa tidak terdapat korelasi bermakna antara usia dan diameter vena kava inferior.

Data korelasi antara jenis kelamin dan $\mathrm{Qb}$ diukur dengan dengan uji $\mathrm{T}$ yang mendapatkan hasil $\mathrm{Qb}$ pada laki-laki memiliki rerata 166,8 dengan deviasi standar 48,4 sedangkan hasil Qb pada perempuan memiliki rerata 129,6 dengan deviasi standar 73,6 (Tabel 3). Pada analisis statistik digunakan uji $\mathrm{T}$ karena variabel yang digunakan yaitu nominal dan rasio. Hasil analisis uji $\mathrm{T}$ memperlihatkan bahwa terdapat perbedaan bermakna antara nilai rerata laki-laki dan perempuan yaitu laki-laki cenderung memiliki $\mathrm{Qb}$ yang lebih tinggi. Hal ini dapat dikaitkan dengan diameter vena cava inferior pada laki-laki yang lebih besar dibandingkan dengan perempuan. $^{13}$

Pada pasien dengan aliran darah saat dialisis yang belum tercapai seharusnya penyebab dasarnya ditentukan. Disfungsi kateter awal biasanya dikaitkan dengan kateter yang tertekuk atau letak yang buruk, sedangkan disfungsi laten biasanya disebabkan oleh trombosis atau fibrin di ujung kateter. Oleh karena itu bila aliran darah tidak adekuat, maka letak pasien seharusnya diperbaiki terlebih dahulu. Kateterisasi femoralis untuk hemodialisis dapat mengakibatkan trombosis (catheter related deep vein thrombosis/CRDVT) sebesar 32,3 episode CRDVT per 1000 hari kateter, sedangkan vena jugularis interna dikaitkan dengan episode yang lebih sedikit (16,9 episode CRDVT per 1000 hari kateter). Jangka waktu rerata kateterisasi untuk terjadinya CRDVT ialah 15,5 hari dengan standar deviasi 5,04, sedangkan 20,92 hari dengan standar deviasi 7,5 pada individu dengan kateter hemodialisis. Terjadi peningkatan yang bermakna untuk kejadian CRDVT dengan kateterisasi berkepanjangan $(\mathrm{n}=26, P<0,05)$ pada kedua kelompok. Rerata tekanan dialisis vena pada pasien yang memiliki kateter terkait trombosis ialah 29,69 $\mathrm{mmHg}$ dengan standar deviasi $9,75 \mathrm{mmHg}$, yang lebih tinggi dari pasien yang tidak memiliki trombosis terkait kateter $23,22 \mathrm{mmHg}$ dengan standar deviasi 07,01 mmHg. ${ }^{14}$

Aliran darah yang tidak memadai merupakan sinyal kerusakan fungsi kateter, yang sering kali dikaitkan dengan penyumbatan oleh trombosis. Trombosis kateter intraluminal terjadi saat penggumpalan darah sebagian atau total yang akan menutup seluruh kateter.

\section{SIMPULAN}

Dari hasil penelitian ini dapat disimpulkan bahwa tidak terdapat hubungan bermakna antara laju aliran darah $(\mathrm{Qb})$ dan letak ujung kateter lumen ganda femoralis jangka pendek non-tunneling (DLC) namun terdapat kecenderungan adanya hubungan positif lemah. Usia tidak memengaruhi hasil penelitian ini sedangkan jenis kelamin merupakan faktor yang memengaruhi $\mathrm{Qb}$ sehingga merupakan suatu bias pada penelitian ini.

\section{SARAN}

Disarankan pada penelitian lanjut, jenis kelamin perlu disingkirkan sebagai faktor bias. Jumlah sampel yang lebih besar akan lebih akurat memrediksi ada tidaknya hubungan antara Qb dengan letak ujung DLC.

\section{DAFTAR PUSTAKA}

1. Bargman M.B, Skorecki K. Chronic kidney disease. In: Harrison's Principles of Internal Medicine (18 th ed). New York: McGraw-Hill, 2005; p. 1762.

2. Vanholder R. Adequacy of dialysis: a critical analysis. Kidney Int. 1992;42:540-58.

3. National Institute of Diabetes, Digestive, Kidney Diseases. USRDS 2002 annual 
data report: atlas of end stage renal disease in the United States. Bethesda, 2002.

4. Port FK, Ashby VB, Dhingra RK, Roys EC, Wolfe RA. Dialysis dose and body mass index are strongly associated with survival in hemodialysis patients. J Am Soc Nephrol. 2002;13: 1061-6.

5. Hakim RM. Assessing the adequacy of dialysis. Kidney Int. 1990;37:822-32.

6. Owen WF, Lew NL, Liu Y, Lowrie EG, Lazarus JM. The urea reduction ratio and serum albumin concentration as predictors of mortality in patients undergoing hemodialysis. N Engl J Med. 1993;329:1001-6.

7. Collins AJ, Ma JZ, Umen A, Keshaviah P. Urea index and other predictors of hemodialysis patient survival. Am J Kidney Dis. 1994;23:272-82.

8. Sehgal AR, Dor A, Tsai AC. Morbidity and cost implication of inadequate hemodialysis. Am J Kidney Dis. 2001; 37:1223-31.

9. Borzou SR, Gholyaf M, Zandha M, Amini R, Goordazi MT, Torkaman B. The effect of increasing blood flow rate on dialysis adequacy in hemodialysis patients. Saudi J Kidney Dis Transpl. 2009;20(4):639-42.

10. Lewis CA, Allen TE, Burke DR, Cardella JF, Citron SJ, Cole PE, et al. Quality Improvement Guidelines for Central Venous Access for the Society of Interventional Radiology Standards of Practice Committee. J Vasc Interv Radiol. 2003;14:S231-S235.

11. Perhimpunan Nefrologi Indonesia. Konsensus dialisis. Jakarta: Pernefri, 2003.

12. Santoro D, Benedetto F, Mondello P, Pipito N, Barilla D, Spinelli F, et al. Vascular access for hemodialysis: current perspectives. Int $\mathbf{J}$ Nephrol Renovasc Dis. 2014;7:281-94.

13. Patil S, Jadhav S, Shetty N, Kharge J, Puttegowda B, Ramlingam R, et al. Assessment of inferior vena cava diameter by echocardiography in normal Indian population: A prospective observational study. Indian Heart J. 2016;68(3 Supl):S26-S30.

14. Nagar VS, Patel DV, Sajjan B, Chatterjee R. Central venous catheterisationperils and pitfalls in critical care. $\mathbf{J}$ Evolution Med Dent Sci. 2017;6(23): 1890-3. 